Henrik Levinsen is senior lecturer in science didactics at University College Copenhagen. He has a science background in biological oceanography, but has engaged in science education at different educational levels during the last 19 years. His main interest focuses on pre- and in-service teacher training, science teachers' professional development and their use of technology-supported teaching as well as external learning environments. He is currently involved in the development and implementation of honors didactics for pre-service teachers.

Thomas Stuart Lindsay is also senior lecturer at University College Copenhagen, and works with pedagogy and didactics. He has taught in teacher education and worked with teacher's professional development in projects connected with both primary school and other institutions at the secondary educational level.

HENRIK LEVINSEN

Institut for Læreruddannelse, Københavns Professionshøjskole, Danmark

hele@kp.dk

\title{
Skole-virksomhedssamarbejde i naturfagene: erfaringer fra et projektbaseret innovativt undervisningsforløb
}

\begin{abstract}
This paper describes how a school-industry partnership can define and frame problem-based science teaching developed for lower secondary school. Among the identified positive outcomes was that students engaged in working with the authentic problems. Further, the student's possibilities for building relations with the employees during the course was of central importance e.g. when they received feedback. Challenges reflected that the teachers and students were uncomfortable with the innovative problem-based teaching method and had a curricular-dominated view on science education. This was expressed in their concerns about what they see as indistinct connections between work phases and a lack of scientific content. It is proposed to use pedagogical link-making as a tool to create spatiotemporal coherence for the students and make connection between scientific concepts based on examples from the study. Link-making may be particularly relevant when the complexity of teaching increases as in school-industry partnerships.
\end{abstract}

\section{INDLEDNING}

Åben skole har siden 2013-folkeskolereformen været det begreb, man i Danmark bruger om undervisning, der inddrager lokalmiljøet og den øvrige omverden. Reformen gjorde inddragelse af skolernes omverden til et krav, og en senere lovændring betyder, at skolerne nu er forpligtede på at samarbejde med virksomheder. Set i dette lys er det overraskende at udskolingens tre naturfag kun indgik i 4-7 
\% af lærernes senest afviklede åben skole-forløb (Danmarks Evalueringsinstitut 2018). Selv når der tages højde for naturfagenes timetal, virker disse tal lave sammenlignet med, at $59 \%$ af alle adspurgte lærere inddrog åben skole i ét eller flere forløb i det undersøgte skoleår (ibid). Det viser, at variationen er stor på tværs af fag, men det illustrerer også, at anvendelsen af åben skole afhænger af klassetrin. Hvad angår typen af den eksterne aktør er der forskelle både på tværs af klassetrin og fag. I udskolingens naturfag er virksomheder den aktør lærerne oftest samarbejder med.

En af årsagerne til at naturfagslærerne anvender åben skole og skole-virksomhedssamarbejde i mindre udstrækning er, at de ikke føler sig godt nok rustede til opgaven: ad de adspurgte lærere var der en tredjedel ( $\mathrm{n}=1082)$, der "onsker at styrke deres fagdidaktiske kompetencer til hhv. at inddrage lokale virksomheder og at indtænke innovation og entreprenørskab i undervisningen" (Rambøll \& KP 2019). Lærernes ønsker er sandsynligvis blevet forstærket efter indførelsen af de obligatoriske fællesfaglige projektarbejder og den fællesfaglige afgangsprøve i naturfagene fra skoleåret 2016/17. Fællesfaglig projektbaseret naturfagsundervisning kan nemlig med fordel rammesættes som et skole-virksomhedsforløb. Skole-virksomhedsforløb kan bibringe den fællesfaglige naturfagsundervisning autenticitet og gøre den mere virkelighedsnær for eleverne, fx i mødet med virksomhedens medarbejdere (Thomsen 2016). Desuden kan undervisning, der inddrager virksomheder med fordel tage afsæt i samfundsrelevante problemstillinger, hvor der arbejdes løsningsorienteret med innovative arbejdsformer. Samlet set rummer skole-virksomhedssamarbejde altså muligheder for at styrke den fællesfaglige naturfagsundervisning, men trods dette findes der kun få systematiske undersøgelser af, hvordan man integrerer virksomheder i undervisningen (Daugbjerg et al. 2018). Der er således et udtalt behov for at udvide erfaringsgrundlaget for denne form for åben skole i naturfagsundervisningen. Ikke mindst for at kvalificere den efterspørgsel på kompetenceudvikling, der jf. ovenstående er brug for, og som bør adressere opmærksomhedspunkter og konkrete didaktiske løsninger på de udfordringer, som allerede kendes (se fx Krogh og Daugbjerg 2018 og referencer deri). Succesfuld implementering af et innovativt projektbaseret skole-virksomhedsforløb medfører fx ændringer af det traditionelle læringsrum, der udfordrer lærernes fagforståelse, og det introducerer barrierer, der bl.a. knytter sig til netop den traditionelle fagforståelse samt en manglende selvtillid i forhold til fagoverskridende undervisning (Sillasen \& Linderoth 2017). Ikke mindst kræver sådanne undervisningsforløb en ændret lærerrolle, der indebærer evnen til at stilladsere elevernes læring i selve arbejdsprocessen i begrebets oprindelige betydning, dvs. at læreren fortløbende vurderer og tilpasser støtten samt "fader" den, når det vurderes, at eleven(-erne) kan selv (Bruner, 1975; Wood et al., 1976). Endeligt bliver tydelige instruktioner særligt vigtige i sådanne forløb (Kirschner et al. 2006).

Formålet med denne artikel er tredelt: For det første vil vi beskrive og begrunde rammen for det etablerede skole-virksomhedssamarbejde og det innovative undervisningsforløb, vi har udviklet indenfor denne ramme. For det andet vil vi analysere afprøvningen af undervisningsforløbet. Endelig for det tredje vil vi med afsæt i analysen af, hvad samarbejdet konkret tilførte de deltagende klassers naturfagsundervisning, diskutere hvordan man generelt kan kvalificere skole-virksomhedsforløb. Strukturen afspejler undersøgelsens forskningsspørgsmål, der lyder: Hvordan anvendes KIE-modellen som ramme for et skole-virksomhedsforløb med naturfagligt indhold på en måde så undervisningen opleves sammenhængende af eleverne?

\section{PROJEKT NEXT:GREEN}

NEXT:GrEeN-projektet (2017-2019) er knyttet til ambitionen om, at skolen skal åbne sig mere for det omgivende samfund. Det er designet som en interventionsundersøgelse med et mål om at udvikle, implementere og evaluere et konkret undervisningsforløb (herefter NG-forløbet) i samarbejde med fem kommuners skoler og energivirksomheden Amager Ressourcecenter (ARC). I alt ca. 850 elever og deres lærere fra 35 klasser og 14 skoler deltog. Lærerne blev tilbudt et eftermiddagskursus på ARC inden NG-forløbet, hvor fokus var på den innovative arbejdsproces. Nedenfor beskrives kriterierne for designet af NG-forløbet, tilblivelsen af NG-forløbets problemstillinger samt selve undervisningsforløbet. 


\section{Designkriterier og undervisningsforløb}

Udgangspunktet for udviklingen af NG-forløbet var, at vi ville afprøve en form for skole-virksomhedsforløb, der træder ud over det traditionelle endagsbesøg og det velkendte før-under-efter-format (Jordet 2010). NG-forløbet skulle være længerevarende for at eleverne havde mulighed for at opbygge relationer til virksomhedens medarbejdere. Det skulle også struktureres som et projektarbejde baseret på innovative arbejdsformer ud fra en antagelse om, at netop skole-virksomhedsforløb rummer muligheder for at træne elevers innovationskompetencer.

Konkret opstillede vi tre kriterier, som designet af NG-forløbet tog udgangspunkt i:

1. Diverse policy-dokumenter der beskriver rammer for, krav og ønsker til naturfagsundervisningen beskrevet i bl.a. lovteksten til åben skole og i naturfagenes faghæfter og bekendtgørelser.

2. Tilgængelig viden fra pædagogisk/didaktiske teori om, hvad der motiverer elever og har betydning for læring generelt og naturfagsundervisning specifikt.

3. Praktiske og logistiske hensyn.

På denne baggrund valgte vi, at eleverne skulle have mulighed for at anvende NG-forløbet til afgangsprøven; intentionen med åben skole om at inddrage skolernes lokalmiljø var implicit indlejret i projektet (1). Desuden valgte vi, at udviklingen af NG-forløbet skulle have fokus på autenticitet, feedback, innovation og entreprenørskab samt handlekompetence baseret på hvad litteraturen angiver, har betydning for elevers motivation, interesse og læring (Nielsen et al. 2017) (2). Endvidere valgte vi at involvere lærerne minimalt i detailudformningen af NG-forløbet i erkendelse af deres tidsmæssigt begrænsede muligheder, men også fordi vi ønskede at afprøve bestemte didaktiske designprincipper (3). Den vigtigste af disse er KIE-modellen (Kromann-Andersen \& Funch-Jensen 2009), der leder eleverne igennem tre "arbejdsrum": det Kreative rum, hvor fantasien får frit løb, det Innovative rum, hvor idéerne konkretiseres samt det Entreprenante rum, hvor elevernes løsninger omsættes til et konkret realiserbart løsningsforslag. Endelig er forløbet inspireret af engineering (Sillasen et al. 2017), og indeholder de fem kendetegn, man oftest finder i definitioner på projektbaseret naturfagsundervisning: 1) en autentisk problemstilling, 2) undersøgelses- eller designaktiviteter, 3) elevprodukter, 4) samarbejde, og 5) brug af læringsteknologier (Hasni et al. 2016). Et kardinalpunkt var, at undervisningen skulle have afsæt i virkelige og samfundsrelevante udfordringer for virksomheden.

Tabel 1. Pilotafprøvede emner og problemstillinger, der efterfølgende blev sammenlagt jf. farvekode. Borgerinformation udgik.

\begin{tabular}{|c|c|c|}
\hline Emne & Uddybning & Problemstilling \\
\hline Tøj & $\begin{array}{l}\text { Produktionen af tøj er den næstmest forurenende produktion i } \\
\text { verden. Både når tøjet produceres og når det skal smides ud, er det } \\
\text { en udfordring for miljøet. }\end{array}$ & $\begin{array}{l}\text { Hvordan kan vi få tøj på kroppen på en } \\
\text { mere miljøvenlig måde? }\end{array}$ \\
\hline Plast & $\begin{array}{l}\text { Plastaffald er nemt at brænde, men det er faktisk også nemt at } \\
\text { genanvende, hvis det er rent og ikke blandet med andre råstoffer. }\end{array}$ & $\begin{array}{l}\text { Hvordan kan vi sørge for at mindre } \\
\text { plast havner i affaldet og mere } \\
\text { genanvendes? }\end{array}$ \\
\hline $\begin{array}{l}\text { Fastfood- } \\
\text { emballage }\end{array}$ & $\begin{array}{l}\text { Fastfood pakkes ind i mange forskellige typer emballage. Når } \\
\text { maden er spist og emballagen skal smides ud, er den ofte blevet } \\
\text { snavset og våd. Det betyder, at den hverken er særlig nem at } \\
\text { genanvende eller at brænde. }\end{array}$ & $\begin{array}{l}\text { Hvordan kan fastfood pakkes ind på } \\
\text { en mere miljøvenlig måde, når den } \\
\text { også skal blive ved med at være frisk } \\
\text { og lækker? }\end{array}$ \\
\hline
\end{tabular}




\begin{tabular}{|l|l|l|}
\hline $\begin{array}{l}\text { Mini- } \\
\text { elektronik }\end{array}$ & $\begin{array}{l}\text { Der findes elektronik i rigtig mange produkter; også mange steder, } \\
\text { hvor det ikke er særlig synligt fx i fødselsdagskort med musik, } \\
\text { gummisko med lys og legetøj med lyd. De små batterier i } \\
\text { elektronikken indeholder stoffer som er skadelige for miljøet. }\end{array}$ & $\begin{array}{l}\text { Hvordan kan vi sikre, at vores } \\
\text { minielektronik ikke havner i det } \\
\text { almindelige affald? }\end{array}$ \\
\hline $\begin{array}{l}\text { Sammensatte } \\
\text { produkter }\end{array}$ & $\begin{array}{l}\text { Det er vigtigt at genanvende råstofferne i vores affald. Desværre } \\
\text { består rigtig mange af vores produkter af mange forskellige } \\
\text { råstoffer, der kan være svære at skille fra hinanden. }\end{array}$ & $\begin{array}{l}\text { Hvordan kan vi genanvende } \\
\text { sammensatte produkter, så vi sparer } \\
\text { miljøet for affald? }\end{array}$ \\
\hline $\begin{array}{l}\text { Borger- } \\
\text { information }\end{array}$ & $\begin{array}{l}\text { Selvom det kan virke mærkeligt er der stadig mange mennesker i } \\
\text { Danmark, der ikke behandler deres affald på den rigtige måde. Det } \\
\text { betyder, at de smider affald ud, der kan genanvendes og er usikre } \\
\text { på, hvordan man skal sortere sit affald. }\end{array}$ & $\begin{array}{l}\text { Hvordan kan vi sørge for, at alle } \\
\text { danskere ved, hvordan de skal sortere } \\
\text { deres affald og at de faktisk gør det? }\end{array}$ \\
\hline
\end{tabular}

Inden for dette opdrag formulerede ARC seks autentiske problemstillinger i et bæredygtighedsperspektiv, som klasserne kunne vælge imellem (tabel 1). Efter feedback i en pilotfase blev nogle af emnerne lagt sammen, så problemstillingerne nu blev formuleret med udgangspunkt i de tre emner tøj, plast og emballage samt minielektronik og sammensatte produkter.

Begyndelsen på NG-forløbet og elevernes innovative arbejde med at finde løsninger på de autentiske affalds- og miljøproblematikker blev markeret ved, at en ARC-formidler kom på besøg umiddelbart efter at klassen havde valgt problemstilling. Generelt valgte flest klasser plast og emballage (17), tøj blev valgt næst hyppigst (12), mens færrest valgte minielektronik og sammensatte produkter (6). Selvom tilbuddet var for alle klassetrin i udskolingen, var deltagerne primært elever fra 8. klasse (25 klasser).

NG-forløbet kom til at omfatte syv faser (tabel 2). Centralt i hele forløbet var "læringskufferten" - en kasse med en bred vifte af materialer og aktiviteter, der udfordrer, inspirerer og støtter eleverne i at finde løsninger på deres problemstilling.

Tabel 2. NG-forløbet. NG2, NG4 og NG6 er hhv. det kreative, innovative og entreprenante rum i KIE-modellen. "Vejl." er en forkortelse for vejleder.

\begin{tabular}{|l|l|l|l|l|l|l|l|}
\hline Fase & NG1 & NG2 & NG3 & NG4 & NG5 & NG6 & NG7 \\
\hline $\begin{array}{l}\text { Beskrivelse } \\
\text { (timer) }\end{array}$ & $\begin{array}{l}\text { Kickoff } \\
(1,5)\end{array}$ & K & $\begin{array}{l}\text { Oplæg \& rundvisning } \\
(2)\end{array}$ & I & $\begin{array}{l}\text { Pitch \& feedback } \\
(4)\end{array}$ & E & $\begin{array}{l}\text { Præsentation } \\
(1,5)\end{array}$ \\
\hline Lokalitet & Skole & Skole & ARC & Skole & ARC & Skole & Skole \\
\hline Ansvarlig & ARC & Lærer & ARC & Lærer & ARC & Lærer & Lærer/ARC \\
\hline Lærerrolle & Pæd. st $\varnothing t t e ~$ & Vejl. & Deltager og pæd. støtte & Vejl. & Pæd. støtte & Vejl. & Evaluator \\
\hline ARC's rolle & Ekspert og formidler (f2f eller virtuel) & & & Evaluator/ \\
ekspert
\end{tabular}




\section{METODE OG ANALYSERAMME}

Undersøgelsen hviler på et kvalitativt datagrundlag, og er inspireret af et etnografisk forskningsdesign. For både at indfange det oplevede og det observerede og dermed skabe en så nuanceret fremstilling af NG-forløbet som muligt, brugte vi to forskellige metoder til dataindsamling, nemlig interviews og feltobservationer. Nedenfor uddybes brugen af de to metoder. Dataindsamlingerne er foretaget både under og i umiddelbar forlængelse af informanternes deltagerne i projektet.

Interviews af elever, lærere og ARC-formidlere blev foretaget for at få direkte adgang til alle hovedaktørernes stemmer i forhold til deres oplevelse af KIE-modellen som ramme for skole-virksomhedsforløbet. I alt foretog vi fem fokusgruppeinterviews; fire med grupper á tre elever fra to skolers 9. klasser og et med en gruppe på fire formidlere fra ARC. Vi valgte fokusgruppeinterviews først og fremmest fordi, de er gode til at producere koncentrerede fælles fortolkninger (Halkier 2015). Af pragmatiske grunde blev lærerinterviewene foretaget som enkeltmandsinterviews (seks lærere fra seks forskellige skoler). Begge interviewtyper foregik som semistrukturerede interviews med afsæt i en interviewguide, og baserer sig på Brinkmann og Kvale (2014).

Observationer med fokus på eleverne blev foretaget for at dokumentere deres handlinger og for at fastholde deres mundtlige kommunikation og interaktion med hinanden samt med deres lærer og den tilknyttede ARC-formidler. Det var målet at observere alle NG-forløbets faser, og både at observere på forskellige klasser og forskellige klassetrin. I praksis blev dette mål indfriet med tilfældigt udvalgte elevgrupper fra to skoler, som vi observerede i sammenlagt 17 lektioner. Observationerne blev fastholdt som feltnoter i observationsskemaer af den ene af denne artikels forfattere.

Både de transskriberede interviews og observationerne blev kodet af forfatterne i fællesskab i en såkaldt "investor triangulation" (Burke 1997). Analysen er centreret omkring interviewudsagn fra elever, lærerne og ARC-formidlerne suppleret med observationer. Analysekategorierne fra kodningen afspejler de didaktiske fokuspunkter, vi valgte på et teoretisk grundlag i forbindelse med udviklingen af NG-forløbet (se "Designkriterier og undervisningsforløb”). Disse kategorier er efterfølgende blevet tematiseret i tre afsnit, der afspejler strukturen i resultatafsnittet (se nedenfor). I præsentationen af resultaterne har vi udelukkende medtaget interviewudsagn og noter fra observationerne, der understreger og/eller nuancerer hovedfundene.

\section{RESULTATER}

For at svare på om lærerne ved hjælp af det valgte undervisningsdesign kan afvikle et skole-virksomhedsforløb med naturfagligt indhold som opleves sammenhængende af deres elever, undersøger vi, hvordan de sammen med ARC-formidlere understøtter etableringen af sådanne sammenhænge. Vi undersøger i første afsnit ("KIE-modellen som skelet”), hvordan KIE-modellen fungerer som NG-forløbets skelet med henblik på at vurdere modellens egnethed i forhold til at binde forløbets faser sammen. Derefter undersøger vi i afsnittet "Kreativitet, Innovation, Entreprenørskab (KIE) og faglighed", hvordan elever, lærere og ARC-formidlere oplever, at elevernes naturfaglighed og naturfaglige kompetencer understøttes af KIE-arbejdsformen og arbejdet med de autentiske problemstillinger. Endelig undersøger vi i afsnittet "Sammenhængen mellem skole og virksomhed", hvordan undervisningsdesignet faciliterer eleverne, så de bliver i stand til at bygge broer mellem deres arbejde på skolen og på virksomheden.

Vi undersøger altså NG-forløbet i forhold til om: 1) KIE-modellen skaber sammenhæng i det, 2) det understøtter naturfaglig læring, samt 3) det hensigtsmæssigt kobler skole og virksomhed.

\section{KIE-modellen som skelet}

KIE-modellens faser skal hjælpe eleverne ved at anvise mål og retning, så deres idéer ender som løsningsforslag. Undervejs hjælpes eleverne gennem en række iterative processer, hvor løbende feedback ideelt set fører til refleksioner og justeringer undervejs. 
I overensstemmelse med intentionerne viser særligt vores observationer, at KIE-modellens forskellige rum hjælper eleverne med at skabe progression. I den kreative fase (NG2) arbejdede eleverne fx med bestemte aktiviteter, som skulle lede dem til at udvikle idéer, og i det innovative rum (NG4) brugte eleverne udvalget af idéer fra den kreative fase til at udvælge netop den, de mente, var mest realistisk at udføre:

"En af grupperne har haft seks ideer oppe at vende. De tager udgangspunkt i at løse ARC's problemstilling omkring sortering af mikroelektronik. De siger, at ideerne kom ud af det blå, og at de forfulgte hinandens ideer. Nogle af dem har været helt urealistiske, fx en ko der kunne spise elektronik. De fortæller, at de har valgt den bedste ud. De fandt den bedste idé ved at se på, om man kunne udføre den i virkeligheden uden alt for mange problemer. Her var en idé om en robot, der kunne adskille elektronik for svær at realisere. De syntes, det er mest spændende at arbejde videre med noget, man kan i virkeligheden.”

Eleverne her henviser til tidligere arbejde, hvor de har haft mulighed for at komme med "helt urealistiske" idéer.

Om progression fortæller andre elever i interviews, at de kan anvende arbejdsdagens feedback (NG5) til at komme videre hen imod at gøre deres idé til et produkt i den entreprenante fase (NG6):

"Det var det han [ARC-formidleren] brugte tid på: Hvor langt er I, hvad tænker I om det nu, hvad er jeres holdning til det, og så hvad skal I gøre, når I kommer hjem?”.

I dette citat synes eleven at have en opfattelse af, at ARC-formidleren brugte spørgsmål til at hjælpe dem videre, hvilket korresponderer med en ARC-formidlers beskrivelse af feedbackprocessen:

"Jeg plejer også at gøre det meget klart, at de [eleverne] kommer ikke ind for at få feedback, for at jeg skal sige, at "det er en god nok idé eller nej, det er en dårlig idé". Det handler om at tage deres idé og gøre den så god, som den nu engang kan [blive]. Så stiller jeg en masse spørgsmål for at finde ud af, hvor meget har de sat sig ind i det her. Har de bare tænkt over noget abstrakt, og der er ikke noget kød på idéen? Altså, de har ikke undersøgt principperne bag det. Eller har de virkelig været dybt i gang? Der kan man stille nogle meget forskellige spørgsmål ud fra det. Mit formål med det er, at de får nogle spørgsmål, de skal forholde sig til. Og de har en bedre fornemmelse for, hvordan de kan lave den her præsentation også [af deres løsningsforslag]. Det er jo der, vi skal hen."

ARC-formidleren fortæller her, at han giver feedback med henblik på at sikre sig, at idéen ikke er så abstrakt, at det gør det vanskeligt for eleverne at få "kød” på den, og at formålet er, at give feedback, der kan lede eleverne i retning af en præsentation af deres løsningsforslag.

Det var dog langt fra alle elever, der var bevidste om, hvor de var i arbejdsprocessen, som disse svar fra ARC-formidlerne på interviewspørgsmålet "refererer de [eleverne] til jer om at nu er vi i den kreative fase eller innovative fase?" viser:

"Overhovedet ikke".

"Nej. Jeg tror bare de [eleverne] oplevede at de skulle løse opgaver"

ARC-formidlernes opfattelse støttes af elevudsagn som dette, der udtrykker, at det var svært at danne sig overblik over KIE-arbejdsprocessen:

“Jeg tror også, det var fordi, vi ikke havde et overblik. Vi havde ikke set et skema for forløbet, hvor der stod, i den her uge er det det her, den her uge er det det her. Vi fik bare at vide, der er fire uger, og så står vi der to uger inde, og vi sidder stadig og laver papirark...”. 
Når KIE-modellen ikke står stærkere i elevernes bevidsthed, kan det hænge sammen med, at introduktionen lærerne fik til KIE, ikke var tilstrækkelig, selvom de i interviews udtrykte tilfredshed med den hjælp og støtte, de kunne hente i læringskufferten, og anerkender modellens egnethed til at skabe et sprog, hvormed man kan tale om innovationsprocesser.

\section{Delkonklusion}

Uagtet ARC-formidlernes og nogle elevers udsagn om at KIE-modellen var utydelig, fungerer den som et skelet, der binder forløbet sammen støttet af aktiviteterne fra læringskufferten, der er knyttet til de forskellige arbejdsrum. KIE-modellen kan dog ikke i sig selv skabe en oplevelse hos eleverne af et forløb, der hænger sammen.

\section{Kreativitet, Innovation, Entreprenørskab (KIE) og faglighed}

I informationsmaterialet til skolerne lovede projektet at styrke elevernes naturfaglige kompetencer via et autentisk undervisningsforløb, der kobler naturfag til deres hverdag. At NG-forløbet er baseret på KIE-arbejdsprocesserne, blev til gengæld kommunikeret mindre tydeligt, og dette kan have farvet læreres og elevers vurderinger af fagligheden.

KIE-arbejdsformen var uvant for mange af de deltagende lærere, og det synes at have afstedkommet en vis bekymring for fagligheden. Flere steder i materialet er det tydeligt, at lærerne synes, at NGforløbet stiller store krav til dem, idet de ud over at agere vejleder og facilitator for elevernes arbejdsproces, også skal sørge for, at de udfordres på et passende fagligt niveau:

“... [Så] det ikke bliver sådan noget fluffy - nu bygger vi den her fantasimaskine, der kan gøre det her, og så har vi løst et problem. At nogle af de løsninger, de [eleverne] kommer med, kræver en så specifik faglig viden, at det ligger langt ud over deres niveau. Og det kan være udfordringen, synes jeg, som lærer, både at guide dem og også hjælpe dem hen til noget, de faktisk reelt kan undersøge, og forstå hvordan man gør”.

"Hvordan arbejder man innovativt, hvordan styrer man de der processer? At det jo er langt mere krævende som lærer at facilitere det, end det er i en almindelig fagundervisning."

Ud over at være bekymrede for, hvordan de skal anvende KIE-modellen til at facilitere elevernes faglige læring, giver lærerne udtryk for, at KIE-modellen er direkte adskilt fra elevernes faglige læring. Med andre ord: lærerne oplever to parallelle spor i NG-forløbet, der ikke hænger sammen. Dette formuleres også af en ARC-formidler:

"Det er også fordi, nogle lærere er meget sådan: "vi stopper lige her, og så skal vi lige have den kemiske formel for det, I står og snakker om”. Og så er det meget tydeligt, hvad fokus har været. Nogle lærere har fokus på, at: "I skal lære den her KIE-model, og I skal kunne arbejde med den og forstå, hvad I gør”. Og andre har sagt, ”I skal kunne leve op til de her afgangsprøveting. Så I skal kunne de her formler og kunne forklare, hvad der sker i de her processer".

ARC-formidleren beskriver her, hvordan han oplever at lærerne enten fokuserer på KIE-modellen, eller fokuserer på at forberede eleverne til afgangsprøven. ARC-formidleren beskriver samtidig, at nogle lærere forsøgte at inddrage naturfag ved $\mathrm{fx}$ at hæfte kemiske formler på nogle af de processer, eleverne introduceres til på ARC.

Samme type bekymring - eller i hvert fald spekulationer over vægtningen og en eventuel modsætning mellem den innovative arbejdsform og faglighed ses hos eleverne, som dette citat illustrerer:

"Og når man uge efter uge ikke lærer noget, og når jeg så siger okay, men det var godt, at det var kreativt. Så kreativt var det alligevel heller ikke. De prøvede at stille nogle modeller op, og jeg synes ikke rigtig, det fungerede. Så det synes jeg var dårligt ved projektet. Gør det kortere og fokusér kun på kreativitet eller gør det så langt som det er og så faglighed”. 
Hvilke faglige begreber og begrebskonstruktioner eleverne har lært, viser materialet ikke. Men der ses eksempler på, at den innovative arbejdsform og naturfaglige kompetencer går hånd i hånd. Observationerne viser fx, at eleverne både anvender deres undersøgelses- og kommunikationskompetencer som en integreret del af KIE-arbejdsprocessen:

"Gruppen har lavet forsøg, hvor de har opløst opløseligt plastik i varmt og koldt vand, fordi de havde en hypotese om, at plastik ikke kunne opløses i koldt vand. Det ville ødelægge idéen, hvis det ikke blev opløst i f.eks. Norden. De har også lavet pH-målinger, fordi de havde en hypotese om, at der var rester af kemi i vandet efter plastikken. Derudover har gruppen interviewet en professor i kemi fra Københavns universitet, som bekræftede dem i, at opløseligt plastik ikke er anvendeligt nok.” (9. klasse i NG7).

Handlekompetence der er et centralt mål i arbejdet med naturfagenes fællesfagslige fokusområder jf. fagbilagene fremstår også som et tema. I de righoldige eksempler, er der indikationer på to forståelser: en forståelse der omfatter selve arbejdsprocessen inkl. elevernes løsningsforslag, og en anden der afspejler, at eleverne rent faktisk opnår kompetencer, der rækker ud over selve NG-forløbet og ind i hverdagen som en ændret adfærd.

Tegn på førstnævnte er en direkte konsekvens af KIE-arbejdsformen (Nielsen 2015), og er i tråd med konstateringen, at:

"Engineering kan bidrage til at fremme elevers handlekompetence, fordi ingeniørers arbejdsmetode fordrer, at de kan tænke og handle selvstændigt samt opsøge viden til at løse problemer med" (Sillasen et al. 2017).

Når en elev selv sætter ord på sin opfattelse af udbyttet af NG-forløbet henvises til, at han har fået et større indblik i konsekvenserne af menneskets handlinger:

"Der vil jeg så sige, jeg synes, det er interessant på grund af, at plastik er et produkt, vi bruger konstant. Og vi ved allesammen godt, at der selvfølgelig er nogle omkostninger i at skulle lave det. Og der er nogle fatale følger af det. Men at få et lidt større indblik på det. Det har helt sikkert været spændende".

En anden elev giver udtryk for det tilfredsstillende i, at have været med til at udforme et produkt, der kan være med til at løse samfundsmæssige problemstillinger:

“Ja, man følte, man var med til at skabe noget, ligesom det du siger der med, at man godt vil ud i samfundet og lave nogle andre ting med de her løsninger. Så var det rart at komme videre med en løsning, få lavet et produkt. Så mange penge skal der til, og sådan kommer det til at se ud. Komme op og tale med nogle andre, på den måde”.

Som det fremgår anvendte eleverne undervejs handlekompetence sammenfiltret med flere af de naturfaglige kompetencer, herunder undersøgelseskompetencen, som nogle grupper viste, de havde særligt flair for:

“... de [eleverne] ville bare sætte en ekstra skraldespand med hvid [?] og så var der et slogan på "det er til plastik". Og så havde eleverne fandeme været ude at tømme skraldespande i bybilledet for at se, hvor mange procentdele af de skraldedele indeholder egentlig plastik. Det var sådan noget 60-70\%. Det er godt videnskabeligt arbejde i stedet for bare at sige "vi tror der er plastik i." "Vi var lige ude at undersøge, hvor meget plastik der er i". Kan det betale sig at lave en skraldespand? Så får du måske sorteret 5 tons plastik fra om året eller et eller andet. Det gør en forskel. Det synes jeg var superfedt. Og der havde de lavet en eller anden model af det” (ARC-formidler). 
Om de innovative arbejdsprocesser rent faktisk manifesterer sig som handlinger i elevernes hverdag er vanskeligere at bedømme, og genstand for divergerende opfattelser blandt lærere og ARC-formidlere.

\section{Delkonklusion}

Lærerne er bekymrede for, hvordan de kan anvende KIE-modellen til at facilitere elevernes faglige arbejde på et passende niveau. Både lærere og elever ser to parallelle spor gennem forløbet, som de synes er svære at koble; et spor der drejer sig om KIE-modellens innovative arbejdsprocesser, og et spor der drejer sig om det naturfaglige indhold. Lærere og elever oplever simpelthen ikke, at arbejdet med de samfundsrelevante problemstillinger er "rigtig” naturfag. De præsenterede data viser dog eksempler på, at eleverne både arbejder innovativt og anvender naturfaglige kompetencer. Desuden viser de, at arbejdsformen udvikler elevernes naturfaglige handlekompetence.

\section{Sammenhængen mellem skole og virksomhed}

Der blev skabt sammenhæng mellem virksomhed og skole gennem en positiv relation mellem elever og ARC-formidlere. ARC-formidlerne og lærernes indbyrdes rollefordeling, fremstår derimod uafklaret. Her vil vi illustrere, hvad der karakteriserer relationerne mellem elever og ARC-formidlere og den feedback eleverne modtog fra dem samt rollefordelingen mellem lærere og ARC-formidlere.

\section{Relationer}

Pointen med at undersøge elevernes relation til ARC-formidlerne er, at ARC-formidlerne oftest fulgte klasserne gennem hele NG-forløbet, og derfor agerede en slags "brohoved" til virksomheden for eleverne. Elevernes oplevelse af sammenhæng mellem det der foregik på hhv. virksomhed og skole blev forsøgt etableret ved at give dem mulighed for at e-maile til deres ARC-formidler i perioderne mellem de faser, hvor de mødte ARC-formidleren fysisk. En lærer uddyber hvordan relationen opbygges:

"her er det B [navn på ARC-formidler], de skriver til, og de ved, at han tager dem seriøst, og de får svar på det der. De havde klart en forventning om at få svar på de ting. Og han tog dem seriøst, og besvarede dem meget, meget fint. Han havde været ude og tale med de forskellige - dem der vidste noget om teknikken om det ene og det andet og det tredje. Og besvarede deres spørgsmål. Det synes jeg fungerede rigtig godt."

Udviklingen af relationen kan ifølge en anden lærer tilskrives, at eleverne forpligter sig overfor ARCformidleren:

"Så der er jo nok helt sikkert opbygget en relation med, at de har snakket om nogle ting, som har sat noget i gang, at de skulle hjem og finde et eller andet, som de så godt ville vise hende. Så der er jo, tænker jeg, en relation hvor hun har, på en eller anden måde, opstillet en forventning om at nu kommer hun og skal høre, hvad er det, de er kommet frem til, ik?”.

Man kan spekulere i, om elevernes kontakt med og relation til ARC-formidlerne resulterede i, at der blev sat spørgsmålstegn ved ARC-formidlernes troværdighed som fagpersoner, men det er der ikke noget, der tyder på. At ARC-formidlerne ikke er autentiske vidensmedarbejdere forstået som faglige eksperter men netop formidlere af specialviden, betyder i hvert fald ikke noget for eleven, som i et interview siger:

"Også fordi vi havde nogle, der kom ude fra ARC, og kunne fortælle om, at de faktisk stod med det til hverdag. Og ved også at komme ud og mødte det. Fordi fra vi gik i 1. klasse og op. Nu har jeg gået på en anden skole, men der har der hvert år været en eller anden emneuge, som har handlet om problemer med vulkaner eller problemer med havstrømme eller et eller andet. Men det er helt sikkert noget andet, når der kommer nogen og fortæller ”jeg arbejder med det her, og jeg har 
faktisk et problem med det til hverdag”. Så det synes jeg helt sikker. Man følte man var mere med på, mere inde i det”.

\section{Feedback}

Fordi eleverne respekterede ARC-formidlerne som vidensautoriteter, kunne man på forhånd formode, at ARC-formidlernes feedback havde en vis resonans hos eleverne. Feedback er som tidligere beskrevet en indbygget del af designprincipperne, og eleverne kan få sparring fra en ARC-formidler både i deres proces med idegenerering og løsningsforslag samt ved den afsluttende præsentation af deres løsningsforslag.

At eleverne værdsatte ARC-formidlernes feedback fremgår tydeligt af følgende udsagn fra to 8.-klasses elever, der bliver bedt om at fortælle om den feedback, de fik på deres ideer i NG5-fasen:

E-1: "Det synes jeg helt klart, var mega fedt."

E-2: "Vi kom i hvert fald meget tættere ind på, hvad vores idé skulle være."

E-1: "[Navn] hjalp med hvad man ligesom skulle fokusere på, fordi vi var lidt lost inden. Men det hjalp rigtig meget, synes jeg."

E-2: "Ja, det var helt klart vigtigt, at vi var derude den dag. Fordi der rent faktisk var nogle som kendte til alt under det område. Hvis vi havde spurgt vores lærere herhjemme, så var det ikke sikkert, at de kunne svare på vores spørgsmål.”

E-1: "Ja også fordi vi havde vejledning med [Navn], hvor han spurgte, hvad status var, og hvor han hjalp med, hvad man skulle fokusere på.”

E-2: "Ja, hvor han virkelig kunne sidde og hjælpe hver og en gruppe, ik"

Eleverne roser altså ARC-formidleren, og tilkendegiver, at feedback'en bragte dem videre i retning af at udvikle deres løsningsforslag. Det fremgår desuden, at eleverne havde stor tiltro til ARCformidlerens faglighed. Lærerne stemmer i:

"Det er jo ret fedt, når man kommer ud til en, der rent faktisk har en masse viden og ... ligesom har rygdækning for at sige nogle af de ting, de siger. At det ikke er deres [elevernes] lærer der altid siger "ej, her kan I arbejde mere". At de så rent faktisk får det fra en der, i deres øjne, repræsenterer noget andet end bare deres sure lærer".

\section{Rollefordeling}

Med et komplekst undervisningsdesign er det tydeligt, at sammenhængen i NG-forløbet var afhængig af de enkelte lærere og ARC-formidlere, og ikke mindst deres indbyrdes relation og evne til at fordele rollerne mellem sig:

“... det er mig og læreren, der står sammen om det, og så bliver der lidt mere ro på, når man står sammen med dem. Første gang står de jo med sådan en "vi ved ikke hvad vi skal”, men efterhånden finder man jo ud af, hvad skal jeg, og hvad skal du" (ARC-formidler).

Rollefordelingen har sandsynligvis haft indflydelse på graden af kobling mellem de forskellige faser i forløbet - særligt koblingen mellem skole og virksomhed: en uudtalt rollefordeling mellem lærer og ARC-formidler kan resultere i, at de forskellige fysiske rum i NG-forløbet af begge parter også opfattes som forskellige mentale rum, hvor de enten er til stede i det ene eller det andet, men ikke i begge. Dette kan have konsekvenser for elevernes mulighed for at koble skole og virksomhed og dermed skabe sammenhæng i forløbet:

"Så det er når der er ARC på, enten når vi er ude hos dem eller de er her, så laver de [eleverne] det der projekt og ellers laver de [eleverne] opgaverne rundtom fra læringskufferten” (ARCformidler). 
ARC-formidlerne vurderer, at lærerne ofte ikke var forberedte til deres besøg på ARC:

"Det tror jeg nærmest de ikke har 9 ud af 10 gange".

Dette må formodes at have haft en negativ betydning for samarbejdet og forudsætningerne for at skabe et sammenhængende forløb. Men set fra et lærerperspektiv var det netop forventningen, at der kun skulle bruges få ressourcer på forberedelse:

"Vores bevæggrund for at deltage var det her med, at hvis vi skal lykkes med åben skole, så er vi nødt til at trække på ressourcer udefra, så vi er nødt til at komme ud til noget, der er næsten færdig-forberedt. Og vi skal have øvelser, som vi bare kan følge som en bageopskrift, næsten. For ellers er det enormt svært at nå det.“

Her synes altså at fremstå en uklar forventningsafstemning mellem ARC-formidlere og lærere i forhold til forberedelse. Det generelle indtryk fra interviewet med ARC-formidlerne er, at der er en usikkerhed omkring hvilken rolle de skal udfylde, når de er på skolen, bl.a. hvordan de skal opretholde løbende kontakt til eleverne. Om disse problematikker udtrykker en ARC-formidler:

"Der har ikke været nok elev-virksomhed samarbejde i det”.

\section{Delkonklusion}

Både relationsskabelse og feedback fra ARC-formidlerne bidrager til at eleverne bygger bro mellem skole og virksomhed. Omvendt virker en uklar rollefordeling mellem lærer og ARC-formidler sandsynligvis ikke befordrende for elevernes oplevelse af kontinuitet og sammenhæng i NG-forløbet. Det synes derimod at betone nødvendigheden af en overordnet fælles pædagogisk strategi til at tydeliggøre sammenhænge på tværs af skole og virksomhed - helst en som både lærere og ARC-medarbejdere kan bruge.

\section{DISKUSSION}

Skole-virksomhedssamarbejde kan åbne skolen til det omgivende samfund, men som anført i artiklens indledning inddrager kun fă danske naturfagslærere virksomheder i deres undervisning; de efterspørger hjælp til at komme i gang. Set i dette lys har NEXT:GrEeN-projektets undervisningstilbud imødekommet en efterspørgsel fra praksis med et eksempel på, hvordan man kan inddrage lokalmiljøet i udskolingsklassernes fællesfaglige naturfagsundervisning. De systematiske undersøgelser af klasserne der gennemførte NG-forløbet viser, at designet med KIE-modellen som skelet fungerer, at eleverne ofte bringer de naturfaglige kompetencer i spil og at alle naturfagene inddrages i arbejdet med problemstillingerne. Relationsdannelser mellem elever og ARC-formidlere og ARC-formidlernes feedback er også vigtige elementer i forløbet. Endelig viser undersøgelsen, at eleverne finder det motiverende at arbejde handlingsorienteret med samfundsrelevante problemstillinger, som de kan genkende fra deres hverdag.

Ikke desto mindre viser undersøgelsens resultater også, at det er svært at designe og ikke mindst gennemføre skole-virksomhedsforløb, som opleves faglige og sammenhængende. Et spørgsmål der derfor trænger sig på er, hvorfor skole-virksomhedsforløb er så svære at praktisere. Svaret på dette spørgsmål er naturligvis ikke enkelt, men det udspringer af det overordnede fund, at sammenhæng i elevernes læreprocesser kun til en vis grad kan stilladseres af rammer og aktiviteter. Solid kommunikativ mediering mellem den undervisning der foregår i klasselokalet, og den der foregår på virksomheden, er afgørende. Dette bør være et centralt og selvstændigt fokuspunkt, når man øger kompleksiteten i undervisningen - et budskab der indeholder klare paralleller til budskabet i Puntambekar \& Hübscher (2005). Vores samlede indtryk er, at der er et behov for at udvikle de kommunikationsstrategier, lærere og ARC-formidlere anvender i NG-forløbet, og som har betydning for elevers 
progression (McCormick 2004). Som det ses nedenfor kan disse strategier anvendes i alle undervisningssammenhænge. De er blot særligt vigtige, når en virksomhed eller et andet eksternt læringsmiljø inddrages i undervisningen. I afsnittene herunder har vi valgt at fokusere på, hvordan man kan skabe meningsfulde sammenhænge i skole-virksomhedsforløb.

\section{Perspektiver på skole-virksomhedsforløb med pædagogiske koblingsdannelser}

Det er altså ikke mindst skift mellem skole og virksomhed, der understreger behovet for en pædagogisk strategi som lærere og ARC-formidlere kan bruge til at hjælpe eleverne med at skabe faglige sammenhænge på langs mellem forløbets faser såvel som på tværs af virksomhed og skole. Et bud på en sådan strategi findes i teorien "pedagogical link-making”, der er udviklet i forbindelse med både at undervise om og lære naturfaglige begreber (Scott et al. 2011). I dansk regi har teorien været benyttet til at analysere inddragelsen af museer i historieundervisning under betegnelsen pædagogiske koblingsdannelser (Jensen 2019). Der har altså været tilløb til at udvide brugen af pedagogical link-making til at undersøge forbindelsen mellem klasserum og et eksternt læringsmiljø. Teoriens tre forskellige kategorier af pædagogiske koblingsdannelser kan beskrives som mundtlige strategier til at 1) støtte samskabelse af viden, 2) fremme kontinuitet, og 3) opmuntre et følelsesmæssigt engagement (figur 1).

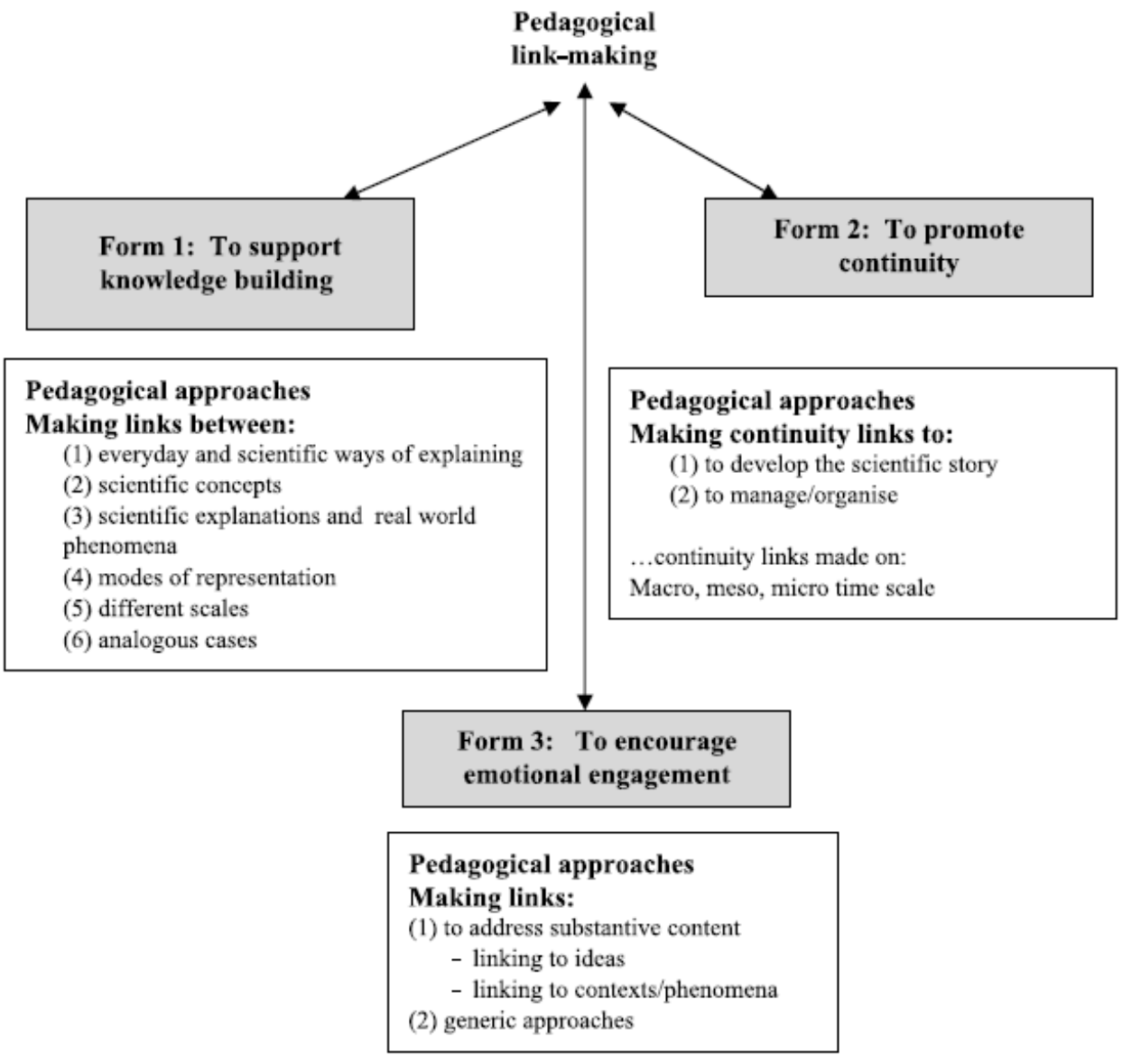

Figur 1. Overblik over de tre kategorier af pædagogiske koblingsdannelser med tilhørende underkategorier (Scott et al. 2011). 
Koblingsdannelser sker hos eleverne som kognitive processer understøttet af læreren gennem forskellige pædagogiske kommunikationsstrategier. Både lærer og elever er altså involverede i processen med at skabe koblingerne: "the teacher to make the link available and the students so that they come to understand the links for themselves as they actively make connections between their own ideas" (Scott et al. 2011). Selvom det kun er eleverne selv, der kan danne koblinger, er pointen, at ansvaret for at skabe de rette betingelser for at danne dem, ligger hos læreren: "It is clear that if link-making is not addressed through teaching, then it is unlikely to emerge in students' learning" (Scott et al. 2011).

Nedenfor vil vi med tre eksempler illustrere, hvordan pædagogiske koblingsdannelser blev brugt i praksis på trods af, at der ikke var fokus på dem i NG-forløbet. Det ene drejer sig om at støtte elevernes mulighed for at skabe faglige forbindelser på tværs af tid og rum - særligt sådan at eleverne kan relatere forløbet til den øvrige naturfagsundervisnings begreber, sammenhænge og erkendelser (kategori 1). Det andet handler om at støtte elevernes oplevelse af kontinuitet (kategori 2), mens det tredje handler om at støtte elevernes oplevelse af sammenhæng ved at engagere dem følelsesmæssigt (kategori 3).

\section{Støtte samskabelse af viden}

Til trods for de omtalte to adskilte spor, findes eksempler på, at lærere forsøgte at lave koblinger mellem aktiviteterne på ARC og naturfagstimerne ved at inddrage naturfaglige begreber og repræsentationsformer, som det fx fremgår af citatet s. 88. Det blev imidlertid kun gjort sjældent. Som citatet også viser, havde lærerne nemlig ofte andre intentioner; nogle fokuserede på selve KIE-arbejdsformen, andre på "teaching to the test". Sidstnævnte kan udtrykke en manglende tiltro til, at innovative skole-virksomhedsforløb som NG-forløbet understøtter elevernes faglige udvikling. Det er imidlertid ud fra teorien om pædagogiske koblingsdannelser helt centralt, at lærerens fokus hele tiden er på elevernes "læring i situationen" for at kunne være parat til at skabe koblinger til elevernes allerede eksisterende viden. Det er via disse in situ koblingsdannelser, at eleverne kan udvikle deres naturfaglige kompetencer og forståelse af, hvordan innovative arbejdsformer kan understøtte deres naturfaglige læring.

\section{Fremme kontinuitet}

Et af formålene med at støtte elevernes koblingsdannelser er, at skole-virksomhedsforløbet skal fremstå meningsfuldt for eleverne. Og det kan det bedst gøre, hvis eleverne kan se, hvordan de naturfaglige kompetencer de erhverver i skolesammenhæng, kan anvendes til at løse samfundsmæssige problemstillinger. Sådanne overordnede koblinger beskrives som koblinger på et makroniveau. Der kan derudover etableres koblinger på et mesoniveau, der dækker over elevernes koblinger på tværs af et enkelt forløb (fx NG-forløbets faser) og et mikroniveau, hvor eleverne danner koblinger inden for en enkelt undervisningssekvens ( $\mathrm{fx}$ mellem forskellige aktiviteter i en af NG-faserne).

Innovative forløb der kendetegnes af høj grad af uforudsigelighed ofte forstærket af, at grupperne arbejder projektbaseret med forskellige problemstillinger, understøtter ikke en logisk eller kronologisk videntilegnelse på samme måde som "normal” klasserums- undervisning. I sådanne forløb er det ekstra vigtigt at guide eleverne gennem de forskellige arbejdsprocesser, hvis undervisningen skal være effektfuld (Kirschner et al. 2006). Konkret kan det gøres vha. spørgsmål, der både afdækker hvor eleverne er (og kommer fra), og peger fremad (mod løsningsforslaget), som eksemplificeret i interviewet s. 87, hvor det fremgår, at ARC-formidleren giver feedback på elevernes løsningsforslag med en spørgeteknik, der understøtter elevernes meningsskabelse på flere niveauer samtidig; elevernes koblinger på mikroniveau understøttes af spørgsmål om, hvor eleverne er i deres proces netop nu, mens koblingsdannelse på mesoniveau understøttes af spørgsmål til principperne bag deres idé formuleret i en tidligere fase i forløbet og spørgsmål til sammenhængen mellem deres nuværende arbejde og det fremtidige løsningsforslag.

Det er imidlertid helt nødvendigt også at anvende principperne fra pædagogiske koblingsdannelser på makroniveau. Som tidligere nævnt forsøgte lærerne kun sjældent at skabe koblinger mellem ele- 
vernes arbejde på ARC og naturfagsundervisningen på skolen. Pointen fra denne undersøgelse er imidlertid, at ARC-formidlerne forholdsvis enkelt kan supplere lærerne ved at stille åbne spørgsmål, der inddrager elevernes tidligere undervisning til trods for, at de ikke selv har deltaget i den. På denne måde hviler skole-virksomhedsforløb ideelt set ikke alene på lærerens kvalifikationer (Daugbjerg \& Pedersen 2018; EVA 2018), men på et reelt samarbejde mellem skole og virksomhed, der begge har opmærksomheden rettet mod at understøtte elevernes koblingsdannelser.

\section{Opmuntre et følelsesmæssigt engagement}

Vores resultater viser, at ARC-formidlerne også på andre måder bidrog til elevernes koblingsdannelser, som har at gøre med den positive relation, ARC-formidlerne skabte til eleverne. Eleverne kunne under hele forløbet henvende sig personligt til ARC-formidlerne, der havde lært dem at kende, og som en lærer udtrykte det, var ARC-formidlerne gode erstatninger for "deres sure lærer". At eleverne tilmed oplevede, at det er en autentisk ekspert, der anerkender deres bidrag til at løse virkelighedstro samfundsudfordringer, kan have forstærket deres motivation for arbejdet og gjort det mere meningsfuldt (Deci \& Ryan 2008). Noget tyder tilmed på at affektive og følelsesmæssige aspekter knyttet til fx relationsdannelse i og omkring undervisningen ikke blot har betydning for elevernes oplevelse af undervisning og læring, men også for deres holdning til naturfagene (Santos \& Mortimer (2003) i Scott et al. 2011; Mortimer \& Scott 2003).

\section{Hindringer for pædagogiske koblingsdannelser i NG-forløbet}

Oplevelsen af manglende faglighed synes at have rod i et konstrueret modsætningsforhold mellem traditionel undervisning, der forbindes med "rigtig" faglighed på den ene side og innovativ undervisning på den anden. Hvor "rigtig" faglighed forbindes med naturfagenes begrebskonstruktioner og sammenhængsforståelse afgrænses innovativ undervisning mere diffust af de forskellige kreative processer, der jo netop er karakteriseret ved, at der ikke er en klar eller entydig sammenhæng mellem undervisningens mål og midler (Andersen 2010).

KIE-modellen er med andre ord medvirkende til, at elever og lærere har svært ved at erkende fagligheden, hvilket synes at lede til, at lærernes forsøg på at støtte elevernes samskabelse af viden ikke lykkes, simpelthen fordi de ikke selv formår at kæde elevernes innovative arbejde sammen med naturfaglighed. Det er altså vanskeligt for lærerne at skabe pædagogiske koblingsdannelser, der støtter elevernes videnopbygning, fordi de oplever, at NG-forløbet er udspændt mellem de innovative arbejdsprocesser, og det de opfatter som det rigtige naturfaglige indhold.

Årsagen til at opdelingen i parallelle innovations- og faglighedsspor fremstår så tydeligt, kan til dels skyldes naturfagenes prøveformer, hvor eleverne især i de skriftlige, særfaglige prøver evalueres ud fra deres evne til at forstå og anvende fagbegreber i mere traditionel forstand. Også i den fællesfaglige mundtlige prøve er evalueringen af de naturfaglige kompetencer i praksis stadig udfordret af et mere traditionelt fagsyn (Krogh og Daugbjerg 2018). Der mangler således givetvis "constructive alignment" jf. Biggs (2003), dvs. klar sammenhæng mellem fagbilag, undervisning og udprøvning. Af ovenstående er det forståeligt, at mere uforudsigelige innovative arbejdsprocesser giver læreren en følelse af manglende kontrol; hvad nu, hvis eleverne ikke făr de relevante (jf. bedømmelseskriterier) fagbegreber i spil?

Et andet rationale angår uforudsigeligheden i sig selv. De innovative arbejdsprocesser stiller læreren i en position, hvor hun/han ikke på forhånd har mulighed for at orkestrere et netværk af sammenhænge mellem faglige begreber og elevernes aktiviteter hverken på et meso- eller makro-niveau. Det betyder, at læreren skal evne at se disse sammenhænge i mens eleverne arbejder for at være i stand til at yde eleverne umiddelbar støtte til selv at kunne se dem.

\section{Muligheder med pædagogiske koblingsdannelser}

I litteraturen har pædagogiske koblingsdannelser været brugt som analyseramme for undersøgelser af, hvordan der skabes sammenhæng i klasserumsundervisning (Rocksén \& Olander 2016). Her 
kan koblingsdannelser på samme måde som andre mundtlige kommunikationsformer være en måde, hvorpå man både kan fremme elevers individuelle og deres fælles konstruktion af forståelse. Desuden kan koblingsdannelser bibringe elever oplevelsen af kontinuitet og progression i undervisningen. Når læring foregår på tværs af forskellige rum som i skole-virksomhedsforløb, er den dialogiske understøttelse af elevernes koblingsdannelser kun belyst i mindre omfang, selvom støtte er afgørende for at forløbet opfattes meningsfuldt og sammenhængende (Jensen 2019). Der findes derfor ikke en generisk forståelse for, hvordan man kan skabe kontinuitet i undervisning, der inddrager eksterne læringsmiljøer. Det er nyt at anvende pædagogiske koblingsdannelser i naturfagsundervisningen på tværs af (fysiske) kontekster, men vi vurderer, at kategorierne i pædagogiske koblingsdannelser kan være egnede både i praksis og til planlægning og analyse af undervisningsforløb, der inddrager virksomheder og andre eksterne læringsmiljøer. Det vil være op til fremtidige undersøgelser empirisk at verificere denne vurdering.

\section{ACKNOWLEDGEMENTS}

Forfatterne ønsker at sende en stor tak til lektor ph.d. Anders Vestergård Thomsen, Professionshøjskolen Absalon. Uden ham var denne artikel ikke blevet til.

\section{REFERENCER}

Andersen, H. L. (2010). “Constructive alignment” og risikoen for en forsimplende universitetspædagogik. Dansk Universitetspædagogisk Tidsskrift 9, 30-35.

Andersen, M. F., Levinsen, H., Møller, H. H., \& Thomsen, A. V. (2020). Building bridges between school and a science center using a flipped learning framework. Journal of Museum Education, 45(2), 200-209. https://doi.org/10.1080/10598650.2020.1744238

Biggs. J. (2003). Teaching for Quality Learning at University. Society for Research into Higher Education and Open University Press (Buckingham).

Brinkmann, S., \& Kvale, S. (2014). Interviews: Learning the craft of qualitative research interviewing (3rd ed.). Los Angeles: SAGE Publications, Inc.

Bruner, J. S. (1975). From communication to language: A psychological perspective. Cognition, 3, $255-287$.

Burke, J. R. (1997). Examining the validity structure of qualitative research. Education, 118(2), 282-293.

Åben skole - en kortlægning af skolernes samarbejde med omverdenen (2018). Danmarks Evalueringsinstitut (https://www.eva.dk).

Daugbjerg, P. S., \& Pedersen, T. (2018). Sammen skaber vi fremtiden skole - et projekt om skole-virksomhedssamarbejde. Mona, 1, 40-56.

Daugbjerg, P. S., Pedersen, T., \& Mikkelsen, T. (2018). Skole-virksomhedssamarbejde og den fællesfaglige undervisning. Mona, 1, 82-92.

Deci, E. L., \& Ryan, R. M. (2008). Self-determination theory: A macrotheory of human motivation, development, and health. Canadian Psychology/Psychologie canadienne, 49(3), 182-185. https://doi.org/10.1037/aoo12801

Folkeskolereformen 2013. Lov om ændring af lov om folkeskolen og forskellige andre love: https:// www.retsinformation.dk/eli/lta/2013/1640

Hasni, A., Bousadra, F., Belletête, V., Benabdallah, A., Nicole, M.-C., \& Dumais, N. (2016). Trends in research on project-based science and technology teaching and learning at K-12 levels: a systematic review. Studies in Science Education, 52(2), 199-231. DOI: 10.1080/03057267.2016.1226573

Jensen, M. E. (2019). Det kulturhistoriske museum som undervisningsressource. Et casestudie af historieundervisning og pædagogiske koblingsdannelser mellem klasserum og museum. Ph.d.-afhandling. Copenhagen. 
Jordet, A. N. (2010). Klasserommet utenfor: tilpasset opplæring i et utvidet læringsrom. Cappelen Akademisk Forlag.

Kirschner, P. A., Sweller, J., \& Clark, R. E. (2006). Why Minimal Guidance During Instruction Does Not Work: An Analysis of the Failure of Constructivist, Discovery, Problem-Based, Experiential, and Inquiry-Based Teaching. Educational Psychologist, 41(2), 75-86. DOI: 10.1207/ s15326985ep4102_1

Kromann-Andersen, E. \& Jensen, I. F. (2009). KIE-modellen - innovativ undervisning i videregående uddannelse. Odense. Praxis

Krogh, L. B., \& Daugbjerg, P. (2018). Fællesfagligheden til prøve. Udfordringer i første års implementering af den fælles prøve i naturfagene i folkeskolen. Mona, 4, 28-54.

McCormick, R. (2004). Issues of learning and knowledge in technology education. International Journal of Technology and Design Education, 14(1), 21-44. dio: https://doi.org/10.1023/B:ITDE.0000007359.81781.7c

Mortimer, E., \& Scott, P. (2003). Meaning making in secondary science classrooms. McGraw-Hill Education (UK). ISBN o 335212077 (pb) o 335212085 (hb)

Nielsen, J. A. (2015). Assessment of innovation competency: a thematic analysis of upper secondary school teachers' talk. The Journal of Educational Research, 108, 318-330

Puntambekar, S. \& Hübscher, R. (2005). Tools for scaffolding students in a complex learning environment: what have we gained and what have we missed? Educational Psychologist, 4O(1): 1.12. DOI: 10.1207/s15326985ep4001_1

Rambøll \& Københavns Professionshøjskole (2019). Undersøgelse af kompetencebehov blandt naturfagslærere i grundskolen. Rapport til Styrelsen for Undervisning og Kvalitet, Børne- og Undervisningsministeriet

Rocksén, M., \& Olander, C. (2016). A topical trajectory on survival: an analysis of link-making in a sequence of lessons on evolution. Research in Science Education 47, 451-472. DOI 10.1007/ S11165-015-9509-3

Scott, P., Mortimer, E., \& Ametller, J. (2011). Pedagogical link-making: a fundamental aspect of teaching and learning scientific conceptual knowledge. Studies in Science Education, 47(1), 3-36. DOI: 10.1080/03057267.2011.549619

Sillasen, M., Daugbjerg, P. S., \& Nielsen, K. (2017). Engineering - svaret på naturfagenes udfordringer. Mona, 2, 64-82.

Sillasen, M. \& Linderoth, U. H. (2017). Tværfaglig undervisning i folkeskolens naturfag. Mona, 3, 19-38.

Thomsen, A. V. (2016). Eksterne partnere i naturfagsundervisningen. Skole-virksomhedssamarbejde - elevers læringsudbytter i naturfag ved samarbejde med virksomheder og mødet med autentisk praksis uden for skolen. Ph.d.-afhandling. DPU, Århus Universitet.

Wood, D., Bruner, J. S., \& Ross, G. (1976). The role of tutoring in problem solving. Journal of Child Psychology \& Psychiatry \& Allied Disciplines, 17(2), 89-100. 